\title{
NILAI-NILAI PENDIDIKAN KARAKTER DALAM AL-QURĀN \\ (THE VALUE OF CHARACTER EDUCATION IN THE QUR'AN)
}

\author{
Musthofa \\ Sekolah Tinggi Agama Islam (STAI) Madiun \\ mustofa030858@gmail.com
}

\section{ABSTRACT}

The values of character education based on teachings that originate from the Qur'an are called the values of character education in the Qur'an. This article is presented sourced from data obtained from the literature sourced from the Qur'an, Al-Hadith and the opinions of experts relating to this discussion. This article is analyzed using the Izwaji Tafsir description method, based on the Qur'an, Al-Hadith and the opinions of experts. This article discusses the formation of the character values of the Qur'an in two ways, namely: First, Faid, namely the abundance of God's gifts in the form of Al-Qur'an character values (honest, fair, patient, thankful, zuhud, devoted, humble, humble, self-control) to someone Allah wants. Second, Iktisäbah, namely the formation of character through human effort, including: (1) Introduction, (2) Understanding, (3) Application, (4) Habit, (5) Compliance, (6) Cultivation, (7) Realizing the character, to form the values of character education are in accordance with the character of the Qur'an.

Keywords: character, fäid, iktisābah.

\section{A. PENDAHULUAN}

Nilai-nilai pendidikan merupakan pedoman dasar pada jiwa seseorang, sejak dini, terutama pada jiwa usia anak sampai dewasa. Nilai-nilai pendi- 
dikan yang didasari pada nilai-nilai pendidikan agama yang tercantum dalam Al-Qurān disebut nilai-nilai pendidikan Al-Qurān.

Nilai-nilai pendidikan Al-Qurān dapat membentuk perubahan jiwa seseorang mempunyai karakter yang sesuai dengan pendidikan nilai-nilai Al-Qurān sehingga perubahan ini membentuk jiwa seseorang berkarakter nilai-nilai Al-Qurān, yaitu budi pekerti perangai yang agung. Nilai-nilai karakter yang didasarkan pada $\mathrm{Al}$-Qurān menunjukkan nilai-nilai karakter yang agung seperti karakter Rasulullah saw:

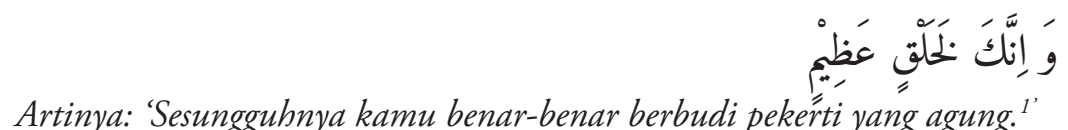

Nilai-nilai pendidikan karakter dalam Al-Qurān dapat ditanamkan kepada seseorang terutama anak didik melalui proses pendidikan karakter. Ini telah diterangkan dalam Al-Qurān:

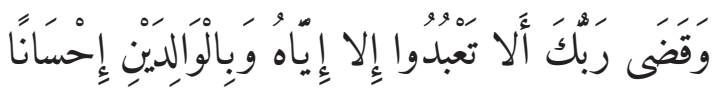

Artinya: DanTuhanmu telah memerintahkan supaya kamu jangan menyembah selain Dia dan hendaklah kamu berbuat baik pada ibu bapakmu dengan sebaik-baiknya. ${ }^{2}$

Nilai-nilai pendidikan karakter dalam Al-Qurān pada ayat tersebut, menunjukkan bahwa Al-Qurān memberikan pendidikan kepada seseorang agar berkarakter tauhid dalam mengabdikan diri kepada Tuhan yang menciptakan hamba-Nya dan berbakti kepada kedua orang tua melalui perilaku yang bernilai ikhsan (kebaikan).

Namun kenyataan yang terdapat pada masyarakat, bahwa adanya beberapa kelompok manusia yang tidak mau menjalankan tugasnya sebagai hamba untuk menyembah kepada Tuhan yang menciptakannya. Dan juga terdapat sebagian manusia yang kurang memperhatikan kepada orang tuanya, bahkan tidak mau mendarmabaktikan nilai-nilai kebaikan kepada kedua orang tuanya, sehingga muncul permasalahan bagaimana cara penanaman nilai-nilai pendidikan karakter dalam Al-Qurān kepada seseorang.

1 Departemen Agama Republik Indonesia, Al-Quran dan Terjemahannya, Jakarta: Mahkota Surabaya, 1989, hal. 960.

2 QS. Al-Isra (17): 23. 
Artikel ini bersumber dari data yang didapat dari ayat-ayat Al-Qurān, Al-Hadiș, dan pendapat para ahli yang berhubungan dengan pembahasan ini. Sebelumnya Ahmad Fuadi dkk sudah pernah membahas tentang nilai-nilai pendidikan karakter dalam $\mathrm{Al}$ qur'an namun ayat yang digunakan berbeda dengan yang dibahasa dalam artikel ini. ${ }^{3}$

Artikel ini dibahas melalui pendekatan Tafsir Izwaji, artinya penjelasan yang didasari atas pemikiran yang bersumber pada Al-Qurān, Al-Hadiṣ, dan pendapat para ulama atau para ahli yang berhubungan dengan pembahasan ini.sedangkan artikel terdahulu yang di tulis oleh Muh. Mawangir membahas pendiidkan karakter perspektif tafsir Al Misbah. ${ }^{4}$

Artikel ini disusun melalui sistematika pendahuluan, nilai-nilai pendidikan karakter dalam Al-Qurān, proses penananam karakter dan kesimpulan.

\section{B. NILAI-NILAI PENDIDIKAN KARAKTER DALAM AL- QURĀN}

Sebelum diuraikan tentang nilai-nilai karakter dalam Al-Qurān, di sini terlebih dahulu akan disajikan ta'rif tentang nilai-nilai pendidikan karakter dalam Al-Qurān.

Nilai berasal dari bahasa Inggris value atau valere (bahasa Latin) yang berarti berguna, mampu akan, berdaya, berlaku, dan kuat. Nilai adalah kualitas suatu hal yang menjadikan hal itu dapat disukai, diinginkan, berguna, dihargai, dan dapat menjadi objek kepentingan. ${ }^{5}$ Nilai sama dengan harkat, yaitu karakter suatu hal yang menjadikan hal itu dapat disukai, diinginkan, berguna atau menjadi objek kepentingan. ${ }^{6}$.

Pendidikan adalah usaha sadar dan terencana untuk mewujudkan suasana belajar dan proses pembelajaran agar peserta didik secara aktif mengembangkan potensi dirinya untuk memiliki kekuatan spiritual keagamaan, pengendalian diri, kepribadian, kecerdasan, akhlak mulia, serta keterampilan

\footnotetext{
3 Ahmad Fuadi Romadhon, Achyar Zein, Syamsu Nahar, Nilai-Nilai Pendidikan Karakter Dalam Al-Qur'an Surat Yusuf, Jurnal Edu Religia, Vol. 1 No. 3, Juli September 2017, 369-381 http://jurnal.uinsu.ac.id/index.php/eduriligia/article/ view/985

${ }_{4}$ Muh. Mawangir, Nilai-Nilai Pendidikan Karakter Perspektif Tafsir Al-Mishbah Karya Muhammad Quraish Shihab, JurnalTadrib,Vol. IV No. 1 Juni 2018, 163-180

5 Sjarkawi, Pembentukan Kepribadian Anak Peran Moral Intelektual, Emosional, Dan Sosial Sebagai Wujud Integritas Membangun Jati Diri (Jakarta: PT Bumi Aksara, 2008), h. 29.

6 Loren Bagus, Kamus Filsafat, Jakarta: PT. Gramedia Pustaka Utama, 2005, hal. 713.
} 
yang diperlukan dirinya, masyarakat, bangsa dan negara. ${ }^{7}$

Karakter yaitu watak atau sifat, dapat memperkirakan perilaku individu dalam pelbagai keadaan dan karenanya juga dapat mengindentifikasikan. ${ }^{8}$

Memahami batasan operasional tersebut dapat disimpulkan bahwa nilainilai pendidikan karakter dalam Al-Qurān yaitu kualitas suatu hal yang menjadikan keinginan dan kegunaan dalam kepentingan pendidikan watak atau sifat pada perilaku individu yang bersumber dari dalam Al-Qurān.

Nilai-nilai pendidikan karakter ini didapat dari sebagian ayat-ayat Al-Qurān yaitu:

1. Surat Al-An'am (6) ayat 151-153:

a. Bertauhid (larangan menyekutukan Allah)

b. Berbakti (berbakti kepada orang tua)

c. (Salih) larangan berbuat keji (membunuh anak, takut miskin)

d. Himmah (kemauan kuat)

e. Jujur (larangan mendekati harta anak yatim)

2. Surat Al-Baqarah (2) ayat 262-263

a. Tulus ikhlas (ketika memberi)

b. Tidak menyakiti hati (ketika berbicara)

c. Pemberi maaf

3. Surat Al-Ma'arij (70) ayat 19

a. Keluh kesah

b. kikir

4. Surat Luqman (31) ayat 12-19

a. Hikmah (bijaksana)

b. Syukur (ketika menerima nikmat)

c. Baik hati (memberi nasihat dalam pergaulan)

d. Berbakti (bakti kepada kedua orang tua)

e. Sabar (ketika dalam musibah)

f. Rendah hati (beretika ketika berjalan dan berbicara)

\section{CARA PEMBENTUKAN NILAI-NILAI PENDIDIKAN KARAKTER}

Pembentukan nilai-nilai ini melalui berbagai bentuk riyadah untuk

7 Undang-Undang Republik Indonesia Nomor 20 Tahun 2003 tentang Sistem Pendidikan Nasional, Semarang: Penerbit Aneka Ilmu, tahun 2004.

8 Loran Bagus, Op.Cit, ha;. 392. 
mencari kebaikan dan kesucian jiwa. Riyadah ${ }^{9}$ ditempuh melalui dua cara yaitu fäid dan iktisābah..$^{10}$

\section{Fāid}

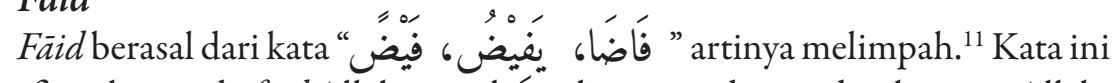
menafigasikan pada fäid Allah yaitu limpahan yang datang dari karunia Allah.

Fäid dari Allah akan dilimpahkan kepada semua orang yang dikehendaki oleh Allah SWT. Allah mempunyai sifat jaiz dan iradat dan qudrat, artinya sifat Allah mempunyai kewenangan untuk berbuat apapun, tak satupun dapat mengganggu atas kewenangannya. Iradat artinya berkehendak. Allah mempunyai sifat berkehendak. Ia menghendaki pada sesuatu atau kepada seseorang yang hendak dituju, untuk menerima limpahan karunia-Nya. Qudrat artinya kuasa. Allah mempunyai sifat untuk menguasai dalam segala hal, dalam melimpahkan karunia-Nya.

Perubahan karakter manusia bukan semata-mata atas usaha seseorang, namun ini merupakan karunia yang dilimpahkan kepada seseorang. Hal ini telah difatwakan oleh Al-Gazali bahwa, Allah mengatur, memperbaiki, menghiasi akhlaq manusia dengan akhlaq mulia. Ia menjaga mereka dengan normanorma kebaikan, dan menjadikan mereka berakhlaq mulia. ${ }^{12}$

Fäid yang terbentuk dari ketiga sifat Allah ini dapat dijadikan sebagai cara untuk mengadakan perilaku-perilaku seseorang yang dibarengi dengan nilainilai karakter yang terdapat di dalam firman-Nya (Al-Qurān).

Fäid adalah bentuk tanda kekuasaan Allah yang harus diimani orang beriman. Salah satu tanda iman seseorang adalah pembenaran (percaya) terhadap sifat Allah bahwa Allah Maha Kuasa untuk menciptakan sesuatu yang tidak diketahui oleh seseorang tentang proses terjadinya sesuatu, sehingga manusia mengetahuinya setelah terwujud adanya sesuatu, misalnya, fäid yang diberikan kepada Nabi Isa as. Beliau diberi karunia oleh Allah berupa kecakapan/kemampuan berbicara ketika masih bayi dalam ayunan. Kemampuan berbicara ini seharusnya dimiliki oleh anak yang sudah cukup umur melalui proses pendidikan. Keterangan ini dapat dielaborasi dalam Al-Qurān surat Ali $\operatorname{Imran}(3)$ ayat 49.

9 Riyadlah yaitu latihan jasmanin dan rohani.

${ }^{10}$ Musthafa, Sufisme Santri Fussaq, Yogyakarta: PT. LkiS Printing Cemerlang, 2005, hal. 31-32.

${ }^{11}$ Mahmud Yunus, Kamus Arab-Indonesia, Jakarta: Hida Karya Agung, tt, hal. 327.

${ }^{12}$ Imam Abu Hamid Muhammad bin Muhammad Al-Gazali, Ihya Ulumuddin, Juz 4, Darbiyah Daru Ihya Al-Kutub, tt, hal. 131. Lihat juga Dewi Purnama Sari, Pendidikan Karakter Berbasis AL Qur'an, Jurnal Islamic Conseling, Vol. 1 No. 1 Tahun 2017.1 - 24 
Fäid Allah yang dikaruniakan kepada hamba-Nya yang bernama Nabi Isa as, ini merupakan nilai karakter pendidikan berupa watak sifat seseorang mempunyai intelegensi, yaitu adanya kemampuan diri berbicara dengan orang yang lain ketika ia belum cukup umur, ini diperoleh tanpa melalui proses pendidikan sebelumnya.

\section{Iktisābah}

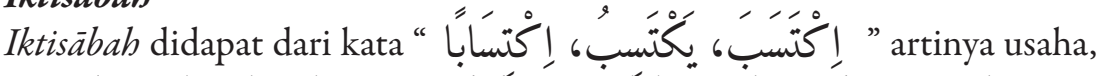
yakni pembentukan karakter yang didapat me任ui usaha. Adapun usaha yang dilakukan melalui proses pengenalan, pemahaman, penerapan, pembiasaan, pengadatan, pembudayaan mewujudkan karakter.

a. Pengenalan

Pengenalan artinya memberi ilmu pengetahuan kepada orang lain tentang nilai-nilai karakter yang tercantum dalam Al-Qurān. Misalnya: jujur, adil, sabar, syukur, zuhud, berbakti, rendah hati, pengendalian diri dan seterusnya.

Pengenalan ini dapat diartikan sebagai memberi ilmu pengetahuan kepada orang lain agar mereka mengetahui tentang ilmu pengatahuan yang berhubungan dengan nilai-nilai karakter dalam Al-Qurān. Hal ini senada dengan metode yang dilakukan oleh Imam Gazali bahwa, beliau dalam membahasa tentang suatu karya tulis, berupa Ihya Ulumuddin, beliau memulainya dengan pengenalan mengenai pentingnya ilmu sebelum mengamalkan suatu pekerjaan tertentu. Rasul saw bersabda:

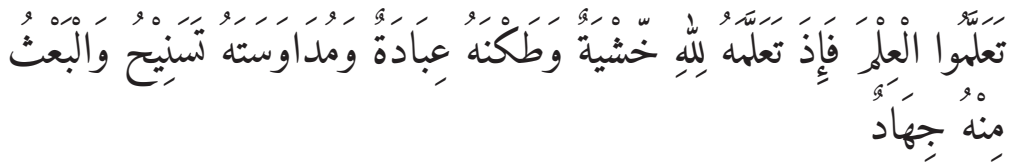

Artinya: Belajarlah (kenalkan) ilmu, karena mengenalkan ilmu sebagai rasa kepada Allah, dan mencarinya merupakan ibadah, mempelajarinya merupakan membaca tasbih, dan membahasnya merupakan jihad. ${ }^{13}$

Pengenalan ilmu dapat menjadikan perubahan pemikiran kepada dirinya, membuka pintu perjalanan ilmu pada hati seseorang, memperluas pandangan, dan memperkuat pekerjaan fisik.

Sesuai dengan hadiș Rasulullah saw:

${ }^{13}$ Imam Abu Hamid Muhammad bin Muhammad Al-Gazali, Ihya Ulumuddin, Juz 1, Kairo: Daru Ihya Al-Kitab Asabiyah, tt, hal. 12. 


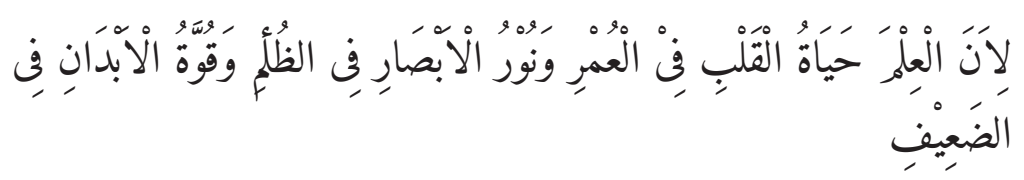

Artinya: Karena ilmu dapat menghidupkan hati dari luka dan menerangi penglihatan dari kegelapan, memperkuat fisik dari kelemahan. ${ }^{14}$

Sehingga pengenalan ilmu pengetahuan tentang nilai-nilai karakter dalam Al-Qurān kepada orang lain melalui pembelajaran dapat menjadikan perubahan, terbuka hati, pencerahan pandangan dan memperkecil pekerjaan fisik yang lemah (semangat fisik).

b. Pemahaman

Pemahaman yaitu suatu proses pembelajaran dengan cara mendengarkan keterangan agar orang lain mengalami perubahan, dengan memahami sesuatu ilmu pengetahuan melalui pandangan, misalnya memahami pengertian syukur, jujur, adil, sabar, zuhud, berbakti, rendah hati dan seterusnya.

Pemahaman dapat dilakukan melalui penglihatan yaitu melihat tulisan agar orang lain mengalami perubahan dengan memahami sesuatu pengetahuan melalui penglihatan mata atau membaca suatu pengetahuan.

Pemahaman suatu ilmu pengetahuan ini pernah dilakukan oleh Rasulullah saw ketika menerima wahyu yang pertama, berupa merintah membaca dengan menyebut Asma Allah. Proses pemahaman yang dilakukan oleh Nabi, diperintah oleh Malaikat Jibril, bahwa beliau diperintah membaca sampai tiga kali. Proses pengulangan sampai tiga kali ini merupakan cara yang dilakukan untuk menuju pemahaman terhadap pentingnya membaca pada ilmu pengetahuan. Diterangkan dalam Tafsir Al-Qurān Al-Adzim, artinya, Rasul berada di dalam Gua Hira, maka Malaikat mendatanginya, menyuruhnya, "Bacalah wahai Rasul." Rasul menjawab, "Saya tidak bisa membaca." Kemudian Malaikat menekan Rasul untuk membaca yang kedua. Rasul menjawab, "Saya tidak bisa membaca." Kemudian Malaikat menekan yang ketiga sampai muncul sikap kesungguhan. Akhirnya, Rasul dapat membaca Quran Surat Al-Alaq (96) ayat $1-5 .{ }^{15}$

${ }^{14}$ Al-Gazali, Ibid, hal. 12.

${ }^{15} \mathrm{Al}-\mathrm{Imam}$ Jalil Al-Hafid Imaduddin Aby Al-Fida Ismail bin Katsir Al-Quraysi Al-Damisqy, Tafsir Al-Qurān Al-Adzim, Juz 4, Semarang: Maktabah wa Mathba'ah Thaha Putra, tt, hal. 527. 
Pemahaman pada suatu ilmu pengetahuan berupa nilai-nilai karakter Al-Qurān dapat berguna bagi dirinya yaitu ilmu pengetahuan yang dimiliki dapat difahami dan dimengerti isi dan maksud yang terkandung di dalamnya, sehingga pemahaman ini dapat diyakini sebagai dasar pengamalan secara pasti, tanpa ada keraguan. Misalnya, pemahaman tentang syukur, seseorang dapat mengerti tentang syukur dan dapat melakukan cara-cara syukur dengan benar sesuai dengan pemahamannya.

Pemahaman pada ilmu pengetahuan nilai-nilai karakter Al-Qurān dapat menjadikan orang berubah menjadi baik perangainya. Pemahaman dapat meresap pada jiwa, kemudian dihayati dan dirasakan, dilakukan dalam bentuk pengamalan. Pengamalan atas dasar pemahaman nilai-nilai karakter Al-Qurān dapat membentuk kepribadian yang baik.

Rasul saw bersabda:

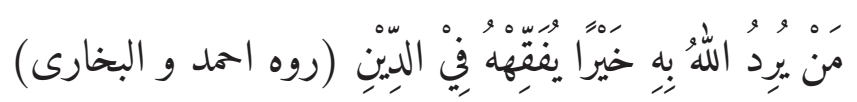

Artinya: Barangsiapa yang Allah inginkan kebaikan padanya, Allah akan faqihkan ia dalam memahami nilai-nilai karakter agama. (HR. Ahmadi dan Buhari). ${ }^{16}$ Nilai-nilai karakter agama ini bersumber dari Al-Qurān.

Sehingga pemahaman ilmu pengetahuan tentang nilai-nilai karakter agama dalam Al-Qurān dapat menjadikan perubahan pemikiran, yang dijadikan sebagai dasar untuk mengamalkannya dan dapat menjadikan pribadi yang baik.

\section{c. Penerapan}

Penerapan artinya pengamalan dari ilmu pengetahuan yang telah dimilikinya. Penerapan ilmu pengetahuan tentang nilai-nilai karakter ajaran dalam Al-Qurān melalui perilaku kehidupan sehari-hari dalam kehidupan sesama manusia. Penerapan nilai-nilai karakter Al-Qurān terhadap sesama manusia dinamakan penerapan hubungan basyariyah, yang dikenal dengan sebutan ukhuwah basyariyah, hubungan ini bertujuan untuk mengenal satu sama lain.

Firman Allah:

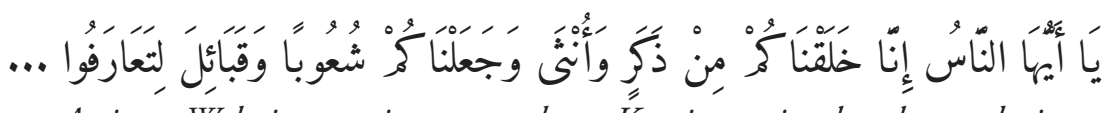

Artinya: Wahai manusia sesungguhnya Kami menciptakan kamu dari seorang

${ }^{16}$ Al-Imam Jalaluddin Abdu Rahman bin Abi Bakar Al-Suyuthi, Al-Jami Al-Shaghir, Bandung: Syirkah Al-Ma’arif, tt, hal. 183. 
laki-laki dan seorang perempuan dan menjadikan kamu berbangsa-bangsa dan bersuku-suku supaya kamu saling kenal-mengenal. ${ }^{17}$

Penerapan nilai-nilai karakter Al-Qurān dapat diterapkan terhadap hak Allah. Ini dilakukan bertujuan untuk mewujudkan bakti kita kepada Allah Dzat Pencipta.

Firman Allah:

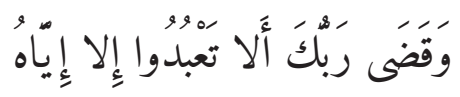

Artinya: Dan Tuhanmu telah memerintabkan supaya kamu jangan menyembah selain Dia .... ${ }^{18}$

Penerapan nilai-nilai karakter Al-Qurān dapat dilakukan pada lingkungan. Ini dilakukan agar dapat terjaga ekosistem demi kelestarian lingkungan agar terjaga dengan baik, sehingg Allah melarang terhadap kerusakan lingkungan.

Firman-Nya:

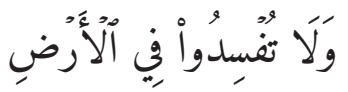

Artinya: Dan janganlah kamu membuat kerusakan di muka bumi. ${ }^{19}$

Penerapan ilmu tentang nilai-nilai karakter Al-Qurān merupakan buah dari ilmu pengetahuan yang dimilikinya. Penerapan ilmu berupa pengamalan ini merupakan sunnah Nabi saw.

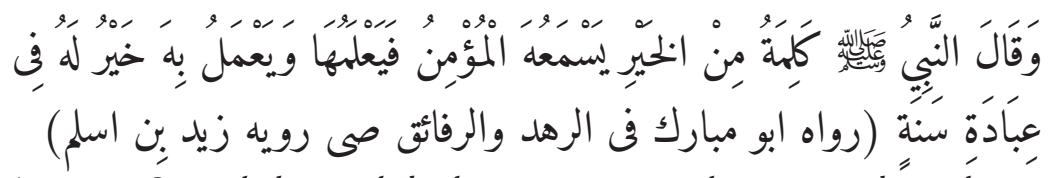

Artinya: Satu kalimat kebaikan seorang mukmin mendengarkan dan mengamalkannya nilainya lebih baik dari ibadah setahun. ${ }^{20}$

Sehingga penerapan dari ilmu yang diperoleh melalui pengenalan, diikuti pemahaman, kemudian diterapkan atau diamalkan. Ini merupakan buah dari ilmu yang telah dimilikinya.

\footnotetext{
17 QS. Al-Hujurat (49): 13.

${ }^{18}$ QS. Al-Isra' (17): 23.

19 QS. Al-A'raaf (7): 56.

${ }^{20}$ QS. Al-A'raaf (7): 56.
} 
d. Pembiasaan

Pembahasan adalah suatu proses penerapan secara berulang-ulang, sehingga menjadi pengamalan yang terbiasa dilakukan

Pembiasaan penerapan nilai-nilai karakter Al-Qurān dapat dilakukan dengan cara melalui pengamalan sehari-hari secara spontan dan alami, tanpa ada perintah atau anjuran. Misalnya, nilai-nilai karakter berupa keadilan. Ini terbentuk melalui proses secara berulang-ulang, alami, tanpa tekanan, berhadapan dengan permasalahan yang menguntungkan atau memungkinkan kepada dirinya, keluarga atau temannya. Nilai-nilai karakter berupa keadilan ini telah ditetapkan dalam Al-Qurān.

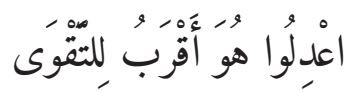

Artinya: Berlaku adillah, karena adil itu lebih dekat kepada takwa. ${ }^{21}$

Pembiasaan nilai-nilai karakter berupa keadilan ini dapat berguna bagi kehidupan manusia. Sebab, dengan keadilan, hukum akan dikerjakan dengan tegak tanpa memandang klaster sosial atau hubungan kekeluargaan. Ini telah dilakukan oleh Sayidina Umar bin Khatab ketika memutuskan hukum yang menimpa kepada anaknya yang bernama Abu Syahmah atas pelanggarannya dalam perzinaan duhukum dengan 80 kali jilid. ${ }^{22}$ Johansyah dalam tulisannya juga menyebutkan bahwa pendidikan karakter dalam aspek perbuatan dapat digunakan metode pembiasaan (habituasi) dan ketauladan (uswah/qudwab). ${ }^{23}$

Pembiasaan nilai-nilai karakter berupa keadilan ini dapat berjalan dengan teratur dapat mengakibatkan terjadinya perlindungan hukum kepada semua orang tanpa pandang bulu.

e. Pengadatan

Pengadatan adalah suatu proses kebiasaan yang dilakukan oleh sekelompok masyarakat. Pengadatan nilai-nilai karakter Al-Qurān dapat dilakukan oleh sekelompok masyarakat secara terorganisir maupun perorangan, didasarkan atas kepercayaan mereka yang berlaku pada suatu

\footnotetext{
${ }^{21}$ QS. Al-Maidah (5): 8

${ }^{22}$ Syeh Muhammad bin Umar Al-Bantany, Tanqihu Al-Qaul Al-Hatsits, Semarang: Maktabah wa Matba'ah Karya Putra, tt, hal. 44.

${ }^{23}$ Johansyah, Pendidikan Karakter Dalam Islam, Kajian dari Aspek Metodologis, Jurnal Ilmiah ISLAM FUTURA, Vol XI No. 1 Agustus 2011.
} 
daerah atau negara.

Pengadatan berupa nilai-nilai karakter Al-Qurān seperti syukur. Syukur adalah salah satu nilai karakter Al-Qurān. Ini dilakukan oleh sekelompok masyarakat apabila mereka merasa menerima nikmat dari Allah sebagai Tuhan-nya. Syukut dapat berupa ucapan lafaz "Alhamdulillah" atau dalam bentuk pemberian sedekah kepada orang lain. Misalnya, syukur disebabkan karena mereka merasakan kenikmatan kemerdekaan Negara Republik Indonesia.

Pengadatan ini dapat berubah menjadi hukum karena adanya perilaku sesuatu yang berulang-ulang sehingga berlaku menjadi kebiasaan dalam bermuamalah di lingkungan sesama manusia. Dalam Waidul Fiqhiyah diterangkan:

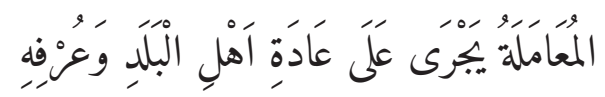

Artinya: Muamalah akan berlaku atas adat penduduk negara dan kebiasaan pada umumnya. ${ }^{24}$

Pengadatan ini dapat mendatangkan manfaat bagi kehidupan masyarakat pada suatu daerah atau negara. Mereka dapat menyatu atau rukun dalam rangka menegakkan adat yang mereka bangun yang bersumber atas muamalah dalam kehidupan sehari-hari, sehingga kewenangan pemberi ijin dalam muamalah pada suatu komunitas suatu daerah atau negara didasari atas persetujuan (ijin) pada pengadatan atau kebiasaan muamalah setempat. Hakikat keabsahan ijin muamalah suatu daerah pada hakikatnya atas dasar kewenangan adat kebiasaan penduduk setempat.

Dalam Usul Fiqih ditegaskan:

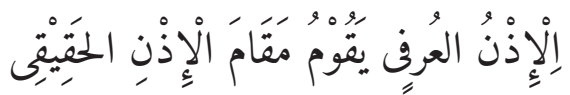

Artinya: Ijin (urfi) adat kebiasaan menempati pada posisi ijin yang sebenarnya. ${ }^{25}$

Sehingga pengadatan dapat dibentuk melalui pengulangan pembiasaan karakter karakter Al-Qurān bagi individu maupun kelompok masya-

${ }^{24}$ Ibid, hal. 1229.

${ }^{25}$ Ali Ahmad Al-Nadwa, Jamharatu Al-Qawaid Al-Fighiyah Fi Al-Muamali Al-Maliyah, Juz 3, Riyadh: Huququ Al-Tab'i Mahfudah Lisyirkati Al-Rajihi Al-Mushrifiyah LIL Istim Tsany, $1421 \mathrm{H}$, hal. 1232. 
rakat, yang menjadi kebiasaan dari mereka sebagai pemegang ijin atas kewenangannya.

f. Pembudayaan

Pembudayaan yaitu proses terjadinya sesuatu dengan cara tertentu menjadi perilaku umat manusia yang merupakan kebudayaan hasil cipta karya mereka pada daerah tertentu.

Pembudayaan nilai-nilai karakter Al-Qurān dapat dilakukan melalui interaksi sosial, artinya mereka dapat menjalin interaksi (hubungan) antara satu dengan yang lain pada aktivitas tertentu, yang terjadi secara berulang-ulang yang menjadi ikatan mereka sebagai karsa, cipta dan karya mereka.

Pembudayaan nilai-nilai karakter Al-Qurān ini dapat berlangsung selama mereka tetap percaya atas karyanya serta mereka pertahankan sesuai dengan kesepakatan mereka. Misalnya, pembudayaan perilaku rendah hati dalam pengertian rendah hati merupakan salah satu nilai karakter Al-Qurān.

Pembudayaan ini dapat dilakukan secara bertahap, artinya melalui seseorang, dengan cara diam-diam, dengan tidak diumumkan secara publikasi, kemudian ditindaklanjuti dengan seruan secara terang-terangan.

Hal ini telah dilakukan oleh Rasulullah saw ketika membudayakan Islam pada awal perkembangan Islam. Menurut M. Sya'labi bahwa, fase yang pertama Rasul menyeru (membudayakan) kepada isteri beliau, Ali putra beliau dan Zaed sahaya beliau. Kemudian dilanjutkan fase kedua, melelaui seruan (pembudayaan) secara umum dan tegas. ${ }^{26}$

Pembudayaan secara perorangan dan secara umum ini didasari firman Allah:

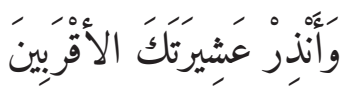

Artinya: Dan berilah peringatan kepada kerabat-kerabatmu yang terdekat. ${ }^{27}$

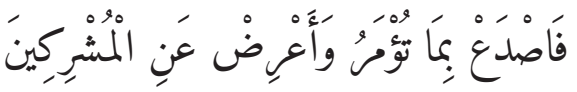

Artinya: Maka sampaikanlah olehmu secara terang-terangan segala apa yang diperintahkan (kepadamu). ${ }^{28}$

${ }^{26}$ M. Sya'labi, Seharag dan Kebudayaan Islam I, Jakarta: PT. Al-Husna Zikra, 2000, hal. 84-86.

27 QS. Al-Syu'ara' (26): 214.

${ }^{28}$ QS. Al-Hijr (15): 94. 
Pembudayaan nilai-nilai karakter Al-Qurān dapat dilakukan melalui interaksi sesama manusia. Artinya menjalankan hubungan sesama manusia dan ditunjukkan di hadapan mereka bahwa tawadu mempunyai nilai kesopanan yang tinggi. Nilai ini merupakan simbul kebaikan jiwa seseorang.

Menurut Teori Interaksi Simbolik yang dipelopori oleh Goerfe Herbert Mead, bahwa makna muncul sebagai hasil interaksi diantara manusia baik secara verbal maupun non verbal. ${ }^{29} \mathrm{Hal}$ itu senada dengan Timothy Rusnak yang mengatakan bahwa pendidikan karakter adalah penanaman nilai etika dalam kehidupan sehari hari. ${ }^{30}$

Pembudayaan tawadu yang merupakan nilai-nilai karakter Al-Qurān, dapat dilakukan melalui penilaian sosial, bahwa tawadu merupakan tanda bukti penerimaan kebenaran bagi orang lain maupun dirinya sendiri. Hal ini disampaikan oleh ulama sufi yang lain:

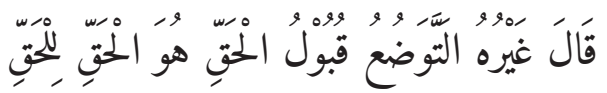

Artinya: Berkata ulama sufi yang lain, tawadu adalah penerimaan kebenaran dari kebenaran terhadap kebenaran. ${ }^{31}$

Dalam Teori Penilaian Sosial diterangkan bahwa sikap tawadu akan mendapat dukungan yang positif dalam kehidupan di masyarakat. Hal ini telah di kenalkan oleh Muzafir Syarif, bahwa seseorang menilai sesuatu pesan dan bagaimana penalaran yang dibuat tersebut dapat mempengaruhi sistem kepercayaan sudah dimiliki sebelumnya. ${ }^{32}$

Ringkasnya, pembudayaan nilai-nilai karakter Al-Qurān dapat dilakukan melalui pengulangan aktivitas, interaksi simbolik dan penialaian sosial, sehingga menduduki sebagai budaya masyarakat.

${ }^{29}$ Morisson, Teori Komunikasi Individu Hingga Massa, Jakarta: Kencana Prenada Media Group, 2013, hal. 110-111.

${ }^{30}$ Timothy Rusnak, The Six Principles of Integrated Character Education, dalam An Integrated Approach to Character Education, California: Corwin Press Inc, 1998, hal. 7. Lihat juga Darwis Hude, Nur Arfiyah Febrianti, Cece Penguatan Pendidikan Karakter Melalui Kearifan Lokal Berbasis Al-Qur'an (Implementasi Di Sman Kabupaten Purwakarta), Jurnal ALIM, Jurnal Of Islamic Education, Vol. 1 ((2) 2019, 335-352

${ }^{31}$ Abu Bakar Muhammad Ishaq Al-Kalabadzi, Attåarafu Li Madzabibi Abli Tasawwuf, Beirut: Daru Al-Kutub Ilmiyah, tt, hal. 114.

${ }^{32}$ Morisson, Op.Cit, hal. 79. 
g. Mewujudkan Karakter

Mewujudkan karakter atau dirasakan yaitu suatu proses perwujudan karakter melalui cara-cara tertentu yang guna untuk menciptakannya dapat diketahui melalui perasaan bagi orang lain maupun dirinya sendiri.

Mewujudkan nilai-nilai karakter Al-Qurān dapat dilakukan melalui internalisasi nilai-nilai karakter Al-Qurān pada jiwa seseorang.

Interaksi nilai-nilai karakter Al-Qurān dapat mengakibatkan diri seseorang menjadi seseorang yang memiliki nilai-nilai karakter Al-Qurān.

Diri seseorang bernilai karakter Al-Qurān dapat dibentuk melalui dialektika (komunikasi dua arah) dari "saya" atau impulsif (kondisi saat seseorang untuk melakukan sebuah tindakan) dari diri, dan "aku" atau sisi sosial manusia. Karakter itu setiap diri seseorang terdiri dari biologis dan psikologis "saya" dan sosiologis "aku". ${ }^{3}$

Wujud nilai-nilai karakter Al-Qurān dapat berupa karakter kesabaran. Seseorang menjadi sabar ini dapat dilakukan oleh orang lain melalui sikap "diri" nya bahwa perilaku "diri"nya dapat diketahui dan dirasakan melalui perasaan orang lain.

Sehingga wujud nilai-nilai karakter Al-Qurān dapat diketahui melalui perasaan, ketika ia melakukannya.

\section{KESIMPULAN}

Nilai-nilai pendidikan karakter yang didasari atas ajaran-ajaran yang bersumber dari Al-Qurān dinamakan Nilai-nilai pendidikan karakter Al-Qurān.

Artikel ini disajikan bersumber dari data yang didapat dari literatur yang bersumber dari Al-Qurān, Al-Hadits dan pendapat para ahli yang berhubungan dengan pembahasan ini.

Artikel ini dianalisa menggunakan metode deskripsi Tafsir Izwaji, berdasarkan Al-Qurān, Al-Hadits dan pendapat para ahli.

Artikel ini membahas tentang pembentukan nilai-nilai karakter Al-Qurān melalui dua cara, yaitu:

Pertama, Fäid, yaitu limpahan karunia Allah berupa nilai-nilai karakter Al-Qurān (jujur, adil, sabar, syukur, zuhud, berbakti, rendah hati, pengendalian diri) kepada seseorang yang Allah kehendaki;

Kedua, Iktisābah, yaitu pembentukan karakter melalui usaha manusia,

\footnotetext{
${ }^{33}$ Margaret M. Polma, Sosiologi Kontemporer, Jakarta: PT. Grafindo Persada, 2000, hal. 257.
} 
meliputi: (1) Pengenalan, (2) Pemahaman, (3) Penerapan, (4) Pembiasaan, (5) Pengadatan, (6) Pembudayaan, (7) Mewujudkan karakter untuk membentuk nilai-nilai pendidikan karakter sesuai karakter Al-Qurān. 


\section{DAFTAR PUSTAKA}

Ahmad Fuadi Romadhon, Achyar Zein, Syamsu Nahar. "Nilai-Nilai Pendidikan

Karakter Dalam Al-Qur'an Surat Yusuf." Jurnal Edu Religia 1, no. 3 (Juli-September 2017): 369-381.

Ahmad, Ali Ahmadi. Ali. Jamharatu Al-Qawaid Al-Fighiyah Fi Al-Muamali Al-Maliyah. Riyadh: Huququ Al-Tab'i Mahfudah Lisyirkati Al-Rajihi

Al-Mushrifiyah LIL Istim Tsany, $1421 \mathrm{H}$.

Al-Qur'ān dan Terjemahannya. Wakaf dan Pelayanan Tanah Suci, Raja Fuad bin Abdullah, Aziz Al-Saud., n.d.

Bagus, Lorenm. Kamus Filsafat. Jakarta: PT. Gramedia Pustaka Utama, 2005.

Bantany, Syekh Muhammad bin Umar Al-. Tanqihu Al-Qaul Al-Hatsits.

Semarang: Maktabah wa Matba'ah Karya Putra, n.d.

Damasqy, Al-Imam Jalil Al-Hafid Imaduddin Aby Al-Fida Ismail bin Katsir

Al-Quraysi Al-. Tafsir Al-Qurān Al-Adzim. Semarang: Maktabah wa Mathba'ah Thaha Putra., n.d.

Darwis Hude, Nur Arfiyah Febrianti. "Penguatan Pendidikan Karakter Melalui Kearifan Lokal Berbasis Al-Qur'an (Implementasi Di Sman Kabupaten Purwakarta)." Jurnal ALIM, Jurnal Of Islamic Education, Vol. 1 ((2) 2019, 335-352 1, no. 2 (n.d.): 335-352.

Gazali, Imam Abu Hamid Muhammad bin Muhammad Al-. "Ihya Ulumuddin Juz 1." Kairo: Daru Ihya Al-Kitab Asabiyah, n.d.

Gazali, Imam Abu Hamid Muhammad bin Muhammad Al-. "Ihya Ulumuddin Juz 4." Darbiyah Dari Ihya Al-Kutub, n.d.

Johansyah. "Pendidikan Karakter Dalam Islam, Kajian dari Aspek Metodologis." Jurnal Ilmiah ISLAM FUTURA XI, no. 1 (Agustus 2011).

Kalabadzi, Abu Bakar Muhammad Ishaq Al-. "Atta’arafu Li Madzahibi Ahli Tasawwuf." Beirut: Daru Al-Kutub Ilmiyah, n.d.

Mawangir, Muh. "Nilai-Nilai Pendidikan Karakter Perspektif Tafsir AlMishbah Karya Muhammad Quraish Shihab." Jurnal Tadrib IV, no. 1 (Juni 2018): 163-180.

Morisson. Teori Komunikasi Individu Hingga Massa. Jakarta: Kencana Prenada Media Group, 2013.

Musthafa. Sufisme Santri Fussaq. Yogyakarta: PT. LKiS Printing Cemerlang, 2005.

Polma, Margaret M. Sosiologi Kontemporer. Jakarta: PT. Grafindo Persada, 2000.

Rusnak, Timothy. "The Six Principles of Integrated Character Education." In 
An Integrated Approach to Character Education. California: Corwin Press Inc., 1998.

Sari, Dewi Purnama. "Pendidikan Karakter Berbasis AL Qur'an." Jurnal Islamic Conseling 1, no. 1 (2017).

Sjarkawi. Pembentukan Kepribadian Anak Peran Moral Intelektual, Emosional, Dan Sosial Sebagai Wujud Integritas Membangun Jati Diri. Jakarta: PT Bumi Aksara, 2008.

Suyuthi, Al-Imam Jalaluddin Abdu Rahman bin Abi Bakar Al-. Al-Jami AlShaghir. Bandung: Syirkah Al-Ma'arif, n.d.

Undang-Undang Republik Indonesia Nomor 20 Tabun 2003 tentang Sistem Pendidikan Nasional. Semarang: Penerbit Aneka Ilmu, 2004.

Yunus, Mahmud. Kamus Arab-Indonesia. Jakarta: Hida Karya Agung, n.d. 